\title{
MENINGKATKAN KETERAMPILAN MOTORIK HALUS ANAK MELALUI KEGIATAN MENEMPEL MENGGUNAKAN SERBUK BAHAN ALAM DI KELOMPOK B TK ISLAM SYAIDUL MUSLIMIN KENDARI
}

\author{
Dorce Banne Pabunga $^{1)}$, Afifah Nur Hidayah ${ }^{1 *}$, Wa Ode Rahmalia ${ }^{1)}$ \\ ${ }^{1}$ Jurusan PG-PAUD, Universitas Halu Oleo. Jln. H.E.A Mokodompit, Kendari 93232, Indonesia.
}

Korespondensi Penulis. Email: afifah.n.hidayah@gmail.com, Telp : 08114056985

\begin{abstract}
Abstrak
Penelitian ini bertujuan untuk meningkatkan terampilan motorik halus anak melalui kegiatan menempel menggunakan serbuk bahan alam. Jenis penelitian ini yaitu penelitian tindakan kelas dengan subyek penelitian adalah anak kelompok B TK Islam Syaidul Muslimin Kendari. Berdasarkan hasil belajar anak didik tentang meningkatkan keterampilan motorik halus anak melalui kegitan menempel menggunakan serbuk bahan alam pada siklus I diperoleh persentase ketercapaian sebesar $53,33 \%$ atau 8 anak didik dan mengalami peningkatan pada siklus II dengan persentase ketercapaian sebesar 86,66\% atau 13 anak didik dari 15 anak. Dengan demikian dapat disimpulkan bahwa motorik halus anak dapat ditingkatkan melalui kegiatan menempel menggunakan serbuk bahan alam si kelompok B TK Islam Syaidul Muslimin.
\end{abstract}

Kata kunci: Keterampilan Motorik Halus, Menempel, Serbuk Bahan Alam

\section{IMPROVING FINE MOTORIC SKILL OF CHILDREN THROUGH STICKING ACTIVITY USING NATURAL MATERIAL POWDER IN GROUP B TK ISLAM SYAIDUL MUSLIMIN KENDARI}

\begin{abstract}
This research aims to improving fine motoric skill of children through sticking activity using natural material powder in group B Tk islam syaidul muslimin kendari. This type of research is class action research with research subjects are group B Tk islam syaidul muslimin kendari. Based on the learning outcomes of students about improving the fine motor skills of children through sticking activity using natural material powder in cycle I obtained the percentage of achievement of $53.33 \%$ or 8 students and increased in cycle II with percentage of achievement of $86.66 \%$ or 13 children students of 15 children. Thus it can be concluded that the fine motor of children can be improved through the activity of sticking using natural material powder in group B TK Islam Syaidul Muslimin Kendari.
\end{abstract}

Keywords: Fine Motor Skills, Sticking, Nature Material

\section{PENDAHULUAN}

Pendidikan Anak Usia Dini (PAUD) di Indonesia diatur dalam Undang-Undang Nomor 20 Tahun 2003 tentang Sistem Pendidikan Nasional pasal 1 ayat 14 yaitu "Pendidikan Anak Usia Dini (PAUD) adalah "suatu upaya pembinaan yang di tujukan kepada anak sejak lahir sampai dengan usia enam tahun yang dilakukan melalui pemberian rangsangan pendidikan untuk membantu pertumbuhan dan perkembangan jasmani dan rohani anak agar memiliki kesiapan dalam memasuki pendidikan lebih lanjut".
Sujiono (2009: 6) menyatakan bahwa pendidikan anak usia dini merupakan salah satu bentuk penyelengaraan pendidikan yang menitikberatkan pada peletakan dasar ke arah pertumbuhan dan perkembangan fisik (koordinasi motorik halus dan kasar), kecerdasan, (daya pikir, daya cipta, kecerdasan emosi, kecerdasan spiritual), sosial emosional (sikap dan perilaku serta beragama), bahasa dan komunikasi, sesuai dengan keunikan dan tahaptahap perkembangan yang di lalui oleh anak usia dini. Masa kanak- kanak di sebut masa keemasan, karena pada masa ini anak lebih mudah menerima rangsangan dari lingkungan untuk menunjang perkembangan jasmani dan 
rohani yang ikut menentukan keberhasilan anak didik di masa mendatang.

Anak usia 5-6 tahun sedang mengalami masa pertumbuhan dan perkembangan dengan pesat. Aspek-aspek perkembangan yang perlu diperhatikan pada anak usia dini diantaranya aspek nilai-nilai agama dan moral, kognitif, bahasa, sosial emosional, dan fisik motorik. Semua aspek ini dapat berkembang dengan baik dengan adanya pengembangan dan pembinaan anak usia dini yang berkualitas. Salah satu perkembangan adalah meningkatkan keterampilan menempel.

Syah (2010: 117) menyatakan bahwa keterampilan adalah Kegiatan yang berhubungan dengan urat-urat syaraf dan otototot (neuromuscular) yang lazimnya tampak dalam kegiatan jasmaniah seperti menulis, mengetik, olahraga, dan sebagainya. Meskipun sifat motorik, namun keterampilan itu memerlukan koordinasi gerak yang teliti dan kesadaran yang tinggi. Dengan demikian, siswa yang melakukan gerakan motorik dengan koordinasi dan kesadaran yang rendah dapat dianggap kurang atau tidak terampil.

Yudha dan Rudhyanto (2005: 7) menyatakan bahwa keterampilan adalah kemampuan anak dalam melakukan berbagai aktivitas seperti motorik, berbahasa, sosialemosional, kognitif, dan afektif (nilai-nilai moral). Keterampilan yang dipelajari dengan baik akan berkembang menjadi kebiasaan. Terdapat hubungan yang saling mempengaruhi antara keterampilan dengan perkembangan kemampuan keseluruhan anak. Keterampilan anak tidak akan berkembang tanpa adanya kematangan. Beberapa faktor yang mempengaruhi keterampilan pada anak yaitu: keturunan, makanan, intelegensi, pola asuh, kesehatan, budaya, ekonomi, sosial, jenis kelamin, dan rangsangan dari lingkungan.

Motorik halus perlu dikembangkan pada anak di TK untuk melatih kekuatan tangan dan melatih koordinasi otot tangan dan mata. Melalui kegiatan menempel anak mampu melatih kekuatan tangan dan mata. Oleh karena itu, biasanya memerlukan kemampuan motorik halus anak adalah gerakan hanya melibatkan bagian-bagian tubuh tertentu saja dan dilakukan oleh otot-otot kecil, seperti keterampilan menggunakan jari-jamari tangan dan gerakan pergelangan tangan yang tepat.

Sumantri (2005: 143) menyatakan bahwa motorik halus adalah keterampilan pengorganisasian penggunaan sekelompok otototot kecil seperti jari jemari dan tangan yang sering membutuhkan kecermatan dan koordinasi mata dan tangan, keterampilan mencangkup: pemanfaatan dan alat-alat untuk berkerja dan objek yang kecil atau pengontrolan terhadap mesin misal mengetik, menjahit dan lain-lain.

Anak pada rentang usia 5-6 tahun berkembangan pesat dalam pengendalian koordinasi yang lebih baik dalam melibatkan otot kecil untuk menggenggam, melempar, menangkap, menulis, menempel atau menggunakan alat (Hurlock, 1978: 150). Caughlin dalam Sumantri (2005: 105-106) menyatakan bahwa pengembangan kegiatan motorik halus anak berdasarkan kronologis usia yaitu: (a) memegang pensil dengan benar antara ibu jari dan dua jari, (b) menjiplak persegi panjang, wajik dan segitiga, (c) memotong bentuk-bentuk sederhana, (d) menggambar orang termasuk: leher, tangan, mulut, rambut dan hidung.

Berdasarkan pengamatan terhadap pembelajaran anak kelompok B di TK Islam Syaidul Muslimin, keterampilan motorik halus anak melalui kegiatan menempelnya masih rendah. Saat diberi kegiatan yang berkaitan dengan menempel sering meminta bantuan guru untuk menyelesaikannya. Bila anak mengerjakan sendiri, hasil karya anak kurang baik. Ini terlihat dari hasil karya anak pada saat mengerjakan kegiatan tersebut. Selama ini guru lebih sering mengembangkan kegiatan keterampilan dalam hal mewarnai, menggambar, melipat dan menulis.

Hasil observasi awal yang dilakukan penulis di TK Islam Syaidul Muslimin kendari pada kelompok B, bahwa keterampilan motorik halus anak melalui kegiatan menempel menggunakan serbuk bahan alam di TK Islam Syaidul Muslimin kendari termaksuk masih tergolong rendah. Kegiatan menempel untuk meningkatkan keterampilan motorik halus anak melalui kegiatan menempel menggunakan serbuk bahan alam yang dilakukan di TK Islam Syaidul Muslimin Kendari masih menggunakan model pembelajaran dan peralatan yang sangat sederhana.

Upaya untuk memecahkan permasalahan tersebut diperlukan penelitian tindakan kelas (PTK) sebagai upaya dalam meningkatkan terampilan motorik halus anak melalui kegiatan menempel menggunakan serbuk bahan alam. 
Sumanto (2005: 94) menyatakan bahwa menempel sering disebut kolase, sedangkan arti kolase adalah kreasi apliksi yang dibuat dengan menggabungkan teknik melukis (lukisan tangan) dengan menempelkan bahan-bahan tertentu seperti kertas berwarna, Koran, kain perca, bijibijian, kapas, ampas kelapa dan lain sebagainya.

Beal (2003: 94) menyatakan bahwa menempel untuk anak usia dini dilakukan dengan memperhatikan beberapa ketentuan. Ketentuan tersebut dibuat untuk dapat memaksimal anak-anak mengoptimalkan segala aspek perkembangannya. Sumanto (2006: 94) menyatakan bahwa manfaat kegiatan menempel yaitu dapat meningkatkan perkembangan otak, bahasa, dan melatih kemampuan motorik halus pada anak. Menempel adalah mengembangkan keterampilan motorik halus anak, jari-jemari anak akan terstimulasi dengan baik dengan selalu melakukan praktek menempel, dapat meningkatkan kemampuan seni rupa, mengembangkan kreativitas sehingga dapat menghasilkan sebuah karya yang indah, anak bangga dengan hasil karyanya.

Misiyanti (2014: 9) menyatakan bahwa kegiatan menempel merupakan salah satu kegiatan pembelajaran yang dapat dilaksanakan untuk membantu perkembangan motorik halus anak. Dengan kegiatan menempel dapat meningkatakan perkembangan motorik halus karena dalam menempel serbuk ini juga dapat melatih otot-otot kecil seprti jari-jemari dan tangan yang sering membutuhkan kecerdasan dan koordinasi mata dan tangan. Kegiatan menempel haruslah dilakukan berulang-ulang agar perkembangan motorik halusnya dapat berkembang dengan baik.

Sudjana (2011: 1) menyatakan bahwa serbuk bahan alam yaitu bahan yang langsung diperoleh dari alam, Serbuk bahan alam adalah bahan yang diperoleh dari alam untuk membuat suatu produk atau karya. Serbuk bahan alam dapat di manfaatkan sebagai media dalam belajar. Cara Mewarnai Serbuk: (1) siapkan wadah kecil (cup/mangkok), (2) masukan pewarna, air dan serbuk kayu/serbuk pasir, kemudian campurkan semua bahan, (3) kemudian serbuk tersebut dipindahkan ke wadah yang datar (tripleks), (4) serbuk daun kering dihancurkan menggunakan tanggan.

Langkah-langkah menggunakan serbuk bahan alam sebagai berikut: (1) Anak memperhatikan penjelasan guru tentang kegiatan menempel, (2) Anak melakukan pengamatan disertai tanya jawab tentang alat dan bahan tentang kegiatan menempel (3) Anak memperhatikan demonstrasi guru tentang cara menggunakan media serbuk bahan alam, (4) Anak diberi kesempatan mencoba memberikan penguatan, (5) Anak praktek Menempel menggunakan media serbuk bahan alam, (6) Anak diberi bimbingan dan membiasakan disiplin dalam menyelesaikan tugas, (7) Anak memajang hasil menempel di depan kelas anak dan guru membahas hasil karya.

\section{METODE}

Jenis penelitian ini yaitu penelitian tindakan kelas. Arikunto (2006: 16) menyatakan bahwa Penelitian Tindakan Kelas (PTK) adalah penelitian yang dimaksudkan sebagai upaya menyelesaikan masalah yang terjadi dalam kelas dengan memperbaiki proses pembelajaran, sehingga dapat mencapai pembelajaran sesuai dengan tujuan yang diharapkan.

Penelitian ini dilaksanakan di Kelompok B TK Islam Syaidul Muslimin Kec. Baruga Kendari. Penelitian ini dilaksanakan pada semester genap tahun pelajaran 2017/2018. Subjek penelitian tindakan ini adalah peneliti dan anak didik pada kelompok B TK Islam Syaidul Muslimin yang berjumlah 15 orang yang terdiri atas 6 anak laki-laki dan 9 anak perempuan dengan retang usia 5-6 tahun. Adapun faktor-faktor yang diteliti dan diamati dalam skripsi adalah sebagai berikut: Faktor anak, faktor guru, faktor hasil belajar anak.

Prosedur pelaksanaan dalam penelitian terdiri dari dua siklus dan masing-masing siklus memuat tiga (3) kali pertemuan

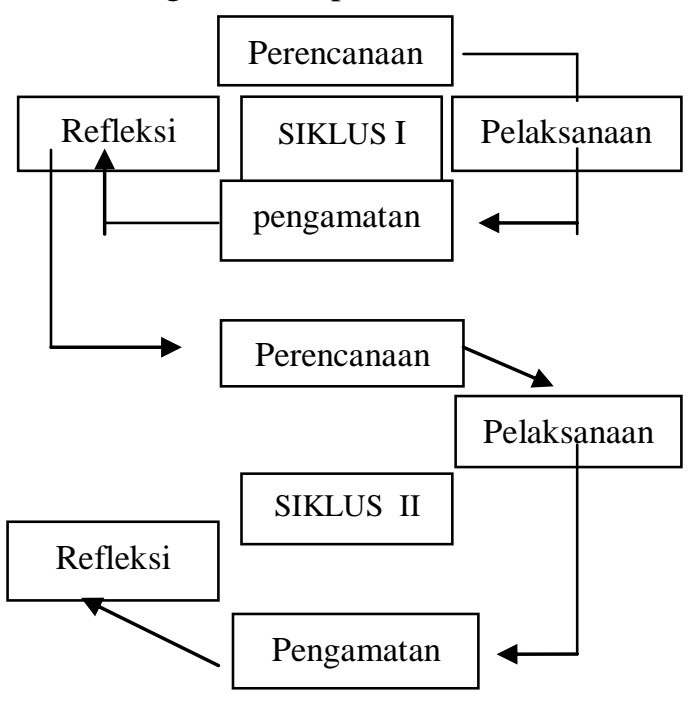

Gambar 1. Peneltian Tindakan Kelas 
Teknik analisis data yang digunakan adalah dengan menggunakan analisis deskriptif. Metode analisis deskriptif adalah metode yang menjelaskan atau menggambarkan fenomena penelitian secara objektif. Analisis data adalah suatu cara menganalisis data selama peneliti mengadakan penelitian. Penelitian ini termaksud penelitian kualitatif menerangkan aktivitas anak dan guru yang diperoleh melalui observasi dan unjuk kerja secara penelitian berlangsung. Selain itu juga mengacu pada pedoman pemberian penilaian dalam satuan pendidikan diTK/RA yaitu dengan penilaian secara kualitatif atau dengan memberikan nilai data bentuk simbol seperti: $*=$ Belum Berkembang $(\mathrm{BB}), * *=$ Mulai Berkembang $(\mathrm{MB}), * * *=$ Berkembang Sesuai Harapan (BSH), $* * * *=$ Berkembang Sangat Baik (BSB). (Depdiknas, 2004: 26).

Teknik dalam pengumpulan data yang digunakan pada pelaksanaan penelitian ini adalah sebagai berikut: Observasi, dokumentasi, wawancara.

Tabel 1. Kategori Keberhasilan Individual dan Klasikal

\begin{tabular}{llll} 
Individual & Klasikal & \multicolumn{2}{l}{ Kategori Simbol } \\
$3,50-4,00$ & $95 \%-100 \%$ & BSB & $* * * *$ \\
$2,50-3,49$ & $85 \%-94 \%$ & BSH & $* * *$ \\
$1,50-2,49$ & $75 \%-84 \%$ & MB & $* *$ \\
$0,01-1,49$ & $<75 \%$ & BB & $*$ \\
\hline \multicolumn{5}{c}{ (Depdiknas, 2004: 26) }
\end{tabular}

Indikator keberhasilan dalam skripsi ini terdiri dari indikator proses dan indikator hasil (nilai). Apabila rencana kegiatan pembelajaran terlaksana minimal $85 \%$ baik secara individu maupun klasikal di kelompok B di TK Islam Syaidul Muslimin Kendari Kec. Baruga kendari, dengan pencapaian nilai Berkembang Sesuai Harapan (BSH) dan berkembang sangat baik (BSB) maka pelaksanaannya dikatakan berhasil.

\section{HASIL DAN PEMBAHASAN}

Berdasarkan permasalahan yang telah dirumuskan dalam penelitian ini, tujuan yang ingin dicapai dalam skripsi ini yaitu untuk meningkatkan keterampilan motorik halus anak melalui kegiatan menempel menggunakan serbuk bahan alam dikelompok B TK Islam Syaidul Muslimin Kendari. Penelitian ini dilaksanakan dalam dua siklus, dimana setiap siklus terdiri dari tiga kali pertemuan sesuai dengan prosedur penelitian yang telah dirancang sebelumnya. Setiap pertemuan terdiri dari tiga tahap yaitu kegiatan awal, kegiatan inti dan kegiatan akhir

Berdasarkan hasil observasi aktivitas mengajar guru pada siklus I memperoleh peresentase keberhasilan sebesar $71,43 \%$ dan mengalami peningkatan pada siklus II sebesar $92,86 \%$. Selanjutnya hasil observasi aktivitas belajar anak didik pada siklus I memperoleh presentase keberhasilan klasikal $64,29 \%$ dan juga mengalami peningkatan pada siklus II sebesar $85,71 \%$.

Berdasarkan observasi awal anak didik tentang keterampilan motorik halus yang dimana hanya 1 orang anak yang mendapatkan nilai bintang $(* * * *)$ atau Berkembang Sangat Baik (BSB) dan 4 orang anak yang mendapatkan nilai bintang $(* * *)$ atau Berkembang Sesuai Harapan (BSH) dengan memperoleh nilai secara klasikal 33,33\%. Pada Siklus I dimana hanya 3 anak didik yang mendapatkan nilai bintang (****) atau Berkembang Sangat Baik (BSB) dan 6 anak didik yang mendapat nilai bintang (***) atau Berkambang Sesuai Harapan (BSH) dengan persetase mencapai $53,33 \%$. Selanjutnya pada Siklus II dimana 5 orang anak didik yang memperoleh nilai bintang $(* * * *)$ atau Berkembang Sangat Baik (BSB) dan 8 orang anak didik yang memperoleh nilai bintang $(* * *)$ atau Berkembang Sesuai Harapan (BSH) dengan persentase ketuntasan klasika $86,67 \%$.

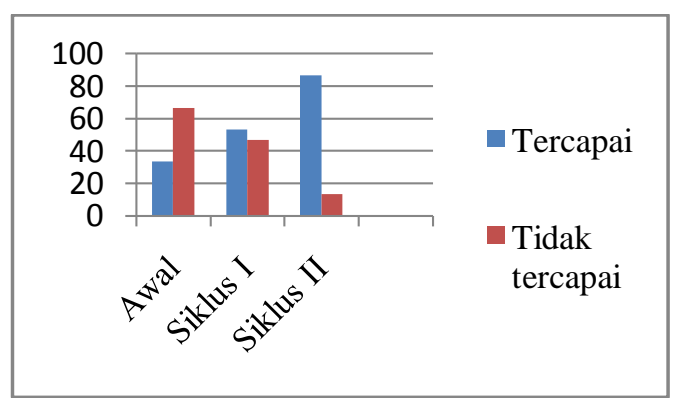

Gambar 1. Hasil Persentase Keberhasilan Klasikal Observasi Awal,Siklus I dan Siklus II

Berdasarkan gambar di atas menunjukkan bahwa keterampilan motorik halus anak melalui kegiatan menempel menggunakan serbuk bahan alam di kelompok B TK Islam Syaidul Muslimin Kendari dapat meningkat.

Tingkat keberhasilan anak pada observasi awal 33,33\%. Dan Hasil evaluasi pada siklus I dapat diketahui bahwa dalam meningkatkan 
keterampilan motorik halus anak melalui kegiatan menempel menggunakan serbuk bahan alam di kelompok B TK Islam Syaidul Muslimin pada siklus I, secara klasikal pada siklus I mencapai tingkat keberhasilan sekitar 53,33\% dengan 15 anak, dimana 3 anak memperoleh bintang $(* * * *)$ atau Berkembang Sangat Baik dengan persentase $20 \%$ dan 6 anak memperoleh nilai bintang $(* * *)$ dengan persentase $40 \%$. Berdasarkan hasil evaluasi tersebut sebagian besar anak sudah dapat melaksanakan kegiatan dengan baik. Dan hasil perhitungan nilai secara klasikal pada siklus II yaitu $86,67 \%$ anak telah mencapai indikator kinerja $85 \%$ anak memperoleh nilai Berkembang Sangat Baik (BSB) dan Berkembang Sesuai Harapan (BSH). Dengan demikian penelitian ini telah berhasil dilaksanakan, maka guru dan observer kelompok B sepakat untuk tidak melanjutkan pada tahap siklus selanjutnya, dengan kata lain tindakan penelitian ini dihentikan.

\section{SIMPULAN DAN SARAN}

\section{Simpulan}

Berdasarkan hasil penelitian ini dapat disimpulkan bahwa motorik halus anak dapat ditingkatkan melalui kegiatan menempel menggunakan serbuk bahan alam di kelompok B TK Islam Syaidul Muslimin Kendari

\section{Saran}

Berdasarkan kesimpulan tersebut, maka peneliti menyarankan hal-hal sebagai berikut :

1. Bagi guru, sebaiknya guru menggunakan kegiatan menempel menggunakan serbuk bahan alam sebagai salah satu cara untuk meningkatkan keterampilan motorik halus anak karena hasil penelitian terbukti bahwa melalui kegiatan menempel dapat menggunakan serbuk bahan alam dapat meningkatakan keterampilan motorik anak

2. Bagi sekolah, diharapkan dapat memperbanyak media yang berkaitan dengan keterampilan menempel untuk menunjang pembelajaran yang dilakukan oleh guru dan anak.

3. Bagi peneliti lain, diharapkan agar skripsi ini dapat dijadikan sebagai bahan rujukan dalam melaksanakan penelitian.

\section{DAFTAR PUSTAKA}

Arikunto, Suharsimi. 2006. Penelitian Tindakan Kelas. Jakarta: Bumi Aksara.

Beal, Nancy. 2003. Rahasia mengajarkan seni pada anak. Yogyakarta: Pripoenbooks.

Depdiknas. 2003. Undang-Undang RI No. 20 Tahun 2003. Sistematis Pendidikan Nasional Jakarta: Citra Umbara.

Hurlock, Elizabeth. 1978. Perkembangan Anak Jilid 1. Jakarta: Erlangga.

Misiyanti, Dkk. 2014. Penerapan Metode Demontsrasi Berbantuan Media Konkret Melalui Kegiatan Kolase untuk Meningkatkan Perkembangan Motorik Halus. Tidak Diterbitkan. Jurnal. Universitas Pendidikan Ganesha Jurusan Pendidikan Guru Pendidikan Anak Usia Dini.

Sujiono, Yuliani Nurani. 2009. Konsep Dasar Pendidikan Anak Usia Dini. Jakarta: PT. Indeks.

Sumantri. 2005. Model Pengembangan Keterampilan Motorik Anak Usia Dini. Jakarta: Depdiknas.

Sumanto. 2005. Pengembangan Kreativitas Seni Rupa Anak TK. Jakarta:Depdiknas

Syah, Muhibbin. 2010. Psikologi Pendidikan. Bandung: PT Remaja Rosdakarya. 